surrounded the conception of "carbon assimilation," or whatever else it was called, has been wonderfully cleared by the adoption of "photosynthesis." It is to be believed that a similar clarifying process would take place, and the thanks of teachers of plant physiology would again be earned by Dr. Barnes, if the word "energesis" could be generally adopted.

\section{Kalamazoo College}

\section{W. E. Praeger}

\section{VOLCANIC ACTIVITY IN ALASTKA}

To the Editor of Science: Mr. Arthur P. Porter, civil engineer and graduate of the Massachusetts Institute of Technology, writing from Elliott Creek, Alaska, under date of May 24, 1907, communicates the following interesting observations:

On and about April 5, several mountains of the Wrangell range in Alaska were active volcanically, sending up great clouds of steam and causing a flood in the Kotsina River that, on April 6, came down past our camp at the mouth of the Kotsina, cut us off from our supply train and prevented our going up the Kotsina on the ice.

To go more into detail, the first we heard about it was on April 1, when we were mushing down the Tonsino River. We stopped for dinner at the camp of some freighters hauling in supplies for the Hubbard-Elliott mine; and Mr. Hubbard said that they could plainly see the smoke (?) and steam rising from Mt. Wrangell. That afternoon and the following day, as we proceeded down the Tonsino and then down the Copper River, we caught occasional distant views of the mountains, but I noted nothing remarkable. (A photograph taken April 2 shows the mountains clear.) On April 5 and 6 we saw great white clouds which always rolled away from the mountains, yet never left them clear; and with the field glasses steam was seen issuing from the sides of the mountains below the tops. We were at the mouth of the Kotsina, about forty miles from the mountains, and could not positively identify the peaks. Apparently, however, Mts. Wrangell, Blackburn and Sanford were all sending up steam.

The next day, April 6, a sudden flood came down the Kotsina on top of the ice and underneath it. There had been no warm weather and no rain $\left(28^{\circ}\right.$ below zero instead). The flood lasted two days and then went down. The enclosed photograph shows the head of the flood advancing down the river and spreading over the snow as it came. I stepped on an ice hummock to take the picture; and by the time I could focus my camera, the flood had passed me on both sides and nearly cut me off. The toe of the flood advanced at the rate of fifty feet a minute, actual timing, eating its way through the snow as if the water were warm.

May 28, the mountains seem to be steaming again (Mt. Drum or Mt. Sanford), and others noted the same two days ago.

W. O. CROSBY

Massachusetts Institute of Technology

\section{RANA PIPIENS}

To the Editor of Science: While I was in charge of the neurological work at the University of Chicago, there were published from the laboratory eight papers dealing with the anatomy of the nervous system of the leopard frog. In these publications the species was designated as Rana virescens brachycephala (Cope). I have recently learned through the kindness of Dr. Leonhard Stejneger, of the National Museum, that this name is no longer used, and that the correct designation for the leopard frog is Rana pipiens (Schreber), as given by Jordan, "Manual of the Vertebrate Animals of the Northern United States," and adopted by Holmes, "Biology of the Frog," 1906, and Miss Dickerson, "The Frog Book," 1906.

In my further studies on the nervous system of the leopard frog, the species will be designated, therefore, as Rana pipiens. In view of the fact that there are several investigations on this species still to be published, I take this opportunity of calling attention to the change in name, first, because those of us who are not specially concerned with taxonomy are apt to be confused by such changes, and second, because $I$ wish to emphasize the fact that these later studies will apply to the same species as that used in the earlier investigations.

Henry H. Donaldson

Wistar Institute of Anatomy 